\title{
Religious Doctrine and Attitudes Toward Vaccination in Jewish Law
}

\author{
Nicole L. Muravsky ${ }^{1} \cdot$ Grace M. Betesh $^{1} \cdot$ Rozalina G. McCoy ${ }^{2,3}$ (D)
}

Accepted: 17 October 2021 / Published online: 27 October 2021

(C) The Author(s), under exclusive licence to Springer Science+Business Media, LLC, part of Springer Nature 2021

\begin{abstract}
Individual and herd immunity against communicable diseases requires high rates of timely and complete vaccination, particularly in closely knit communities, densely populated areas, and places with high influx of potentially infected individuals. Recent outbreaks of COVID-19 and, previously, measles in religious Jewish communities of New York, as well as the rise of vaccine hesitancy in faith communities, call for the examination of Jewish attitudes toward vaccination. In this article, we examine religious doctrine and guidance on vaccination in Orthodox (including Modern Orthodox, Chabad-Lubavich, and Ultra-Orthodox), Conservative, and Reform denominations of Judaism and apply these principles to vaccinations against measles, human papillomavirus (HPV), and COVID-19. We found that the leaders and scholars in these three major denominations of Judaism are uniform in their strong support, often to the point of mandate, for the principles of vaccination. Support for vaccination is deeply rooted in the Torah, Jewish law, and contemporary rulings of poskim (Jewish legal scholars). These principles are applied by each denomination in strong support of measles and COVID-19 vaccination, though there is less certainty in their support of vaccination against HPV.
\end{abstract}

Keywords Judaism · Vaccination · Religion · COVID-19 · Measles · Human papillomavirus $\cdot$ Public health

Nicole Muravsky and Grace Betesh have contributed equally to this work.

Rozalina G. McCoy

mccoy.rozalina@mayo.edu

1 Yeshivah of Flatbush Joel Braverman High School, Brooklyn, NY, USA

2 Division of Community Internal Medicine, Department of Medicine, Mayo Clinic, 200 First Street SW, Rochester, MN 55905, USA

3 Mayo Clinic Robert D. and Patricia E. Kern Center for the Science of Health Care Delivery, Rochester, MN, USA 


\section{Introduction}

More than 44.6 million Americans have been diagnosed with COVID-19 and 718,681 have died as of October 15, 2021(CDC, 2021). Those who survived, now face the prospect of long-term sequela affecting them, their families, and society (Jiang \& McCoy, 2020; Jiang et al., 2021). At the same time, 65.6\% of Americans have received at least one dose of a COVID-19 vaccine and $56.7 \%$ are fully vaccinated (CDC, 2021). As vaccination efforts against COVID-19 continue in the USA and around the world, it is timely to reflect on the experience with other vaccine-preventable diseases and anticipate potential barriers to vaccination that may be unique to communities of faith. This is particularly important as vaccination efforts against COVID-19 have stalled in the USA, resulting in a surge of new infections, hospitalizations, and deaths (CDC, 2021). The record number of measles cases reported in the USA in 2019 after its presumed elimination 19 years earlier was a stark reminder of society's vulnerability to communicable diseases even in the presence of a safe, effective, and widely available vaccine (CDC, 2020). The vast majority of measles cases between the start of the outbreak in 2018 until February 2019 occurred in the New York City borough of Brooklyn and in Rockland County (Andrews, 2019) and are assumed to have been driven by low vaccination rates in the Orthodox Jewish community (CDC, 2020). In 2020, the same communities saw large outbreaks of COVID-19 (Levenson et al. 2020), spurring concerns about Judaism's doctrine on and support for vaccination and sparking a broader debate about religious freedom in the face of public health emergencies and infectious disease outbreaks (Kruzel, 2020). Herein, we examine the Jewish religious doctrine surrounding vaccination, pertinent not only to the $1.9 \%$ of the US population that identifies as Jewish (Pew Research Center, 2015) but potentially to other faith communities that struggled with vaccination efforts as well (Kruzel, 2020; Wang et al., 2014).

In addition to protecting the individual being vaccinated, immunization has the potential to protect one's community. Herd immunity, if it is to be achieved without incurring the costs of illness, requires high rates of timely and complete vaccination, though the exact vaccination rates necessary for herd immunity differ for each pathogen. This is particularly important for closely knit communities, densely populated areas, and places with high influx of potentially infected individuals as well as when dealing with a highly infectious pathogen. In the USA, childhood vaccination efforts are supported and enforced predominantly by school entry requirements. However, vaccination mandates are not unconditional, with medical, religious, and philosophical exemption pathways to opt out of the requirements that vary widely by state (Bednarczyk et al., 2019). Currently, all states allow for medical exemptions to vaccination mandates, 18 states allow for philosophical exemptions (16 states for all vaccines, one state for only the human papillomavirus [HPV] vaccine, and one state for all vaccines except the measles-mumps-rubella [MMR]), and 45 states (all but California, Maine, Mississippi, New York, and West Virginia) and Washington D.C. allow for religious exemptions. While Louisiana and Minnesota do not explicitly recognize religious exemption, they allow religion to be counted toward non-medical exemption. (Immunization Action Coalition 2020, National Conference of State 
Legislatures 2021). Statewide rates of religious and philosophical exemptions correlate directly with infection risk among unvaccinated, under-vaccinated, and even vaccinated individuals (Bednarczyk et al., 2019; Glasser et al., 2016; Salmon et al., 1999; Wang et al., 2014).

Measles outbreaks in Jewish communities of New York in 2018 and 2019, as well as COVID-19 outbreaks in the same communities in 2020, spurred local and state-wide efforts to close vaccination exemption loopholes and increase vaccination rates. As society, public health experts, and policy makers implement one of the most massive and consequential vaccination efforts in generations, a nuanced understanding of religious tenets surrounding vaccination is both timely and relevant. Herein, we focus specifically on Judaism's doctrine toward vaccination because of the recurrent outbreaks of vaccine-preventable diseases in Orthodox Jewish communities in both the USA and Israel.

Nearly $77 \%$ of US adults affiliate with a religious faith and $53 \%$ consider religion to be very important to them (Pew Research Center, 2015). As such, public health organizations seeking to improve vaccination rates need to consider the tenets of different religious groups and tailor interventions to be culturally appropriate and sensitive for the populations they are trying to reach. Our analysis focuses on the Jewish perspectives on vaccination overall and on three vaccines specifically that have been surrounded by some degree of controversy and with different levels of public health enforcement, i.e. the MMR, HPV, and COVID-19 vaccines. Importantly, Jewish communities in the USA and around the world are not monolithic. Haredi (sometimes called Ultra-orthodox), Orthodox, Conservative, and Reform branches of Judaism vary in their traditions and interpretations of the Torah (Hebrew Bible) and Halacha (Jewish jurisprudence and ethics). We therefore address the core principles surrounding vaccination from the perspectives of these common branches of Judaism, apply them to MMR, HPV, and COVID-19 vaccine case studies, and conclude by discussing the implications of these attitudes and regulations on current and future vaccination efforts, including against COVID-19.

\section{Methods}

We queried both secular and religious sources for guidance on vaccines overall and specifically against MMR, HPV, and COVID-19 as of December 2020. Secular literature sources were identified through PubMed and Google Scholar queries for terms "Jewish" or "Judaism", "vaccine" or "vaccination" or "immunization", and "MMR" or "HPV" or "measles" or "mumps" or "rubella" or "human papillomavirus" or "COVID-19". Religious sources were identified by prominent leaders of religious organizations affiliating with the different sects of Judaism. We obtained our data via publicly available search engines and by direct contact with individuals. Core principles identified in the literature and discussed throughout the manuscript are summarized in Table 1. Institutional Board Review was not required for this work, as it is a summary of existing literature and does not involve human subjects research. 


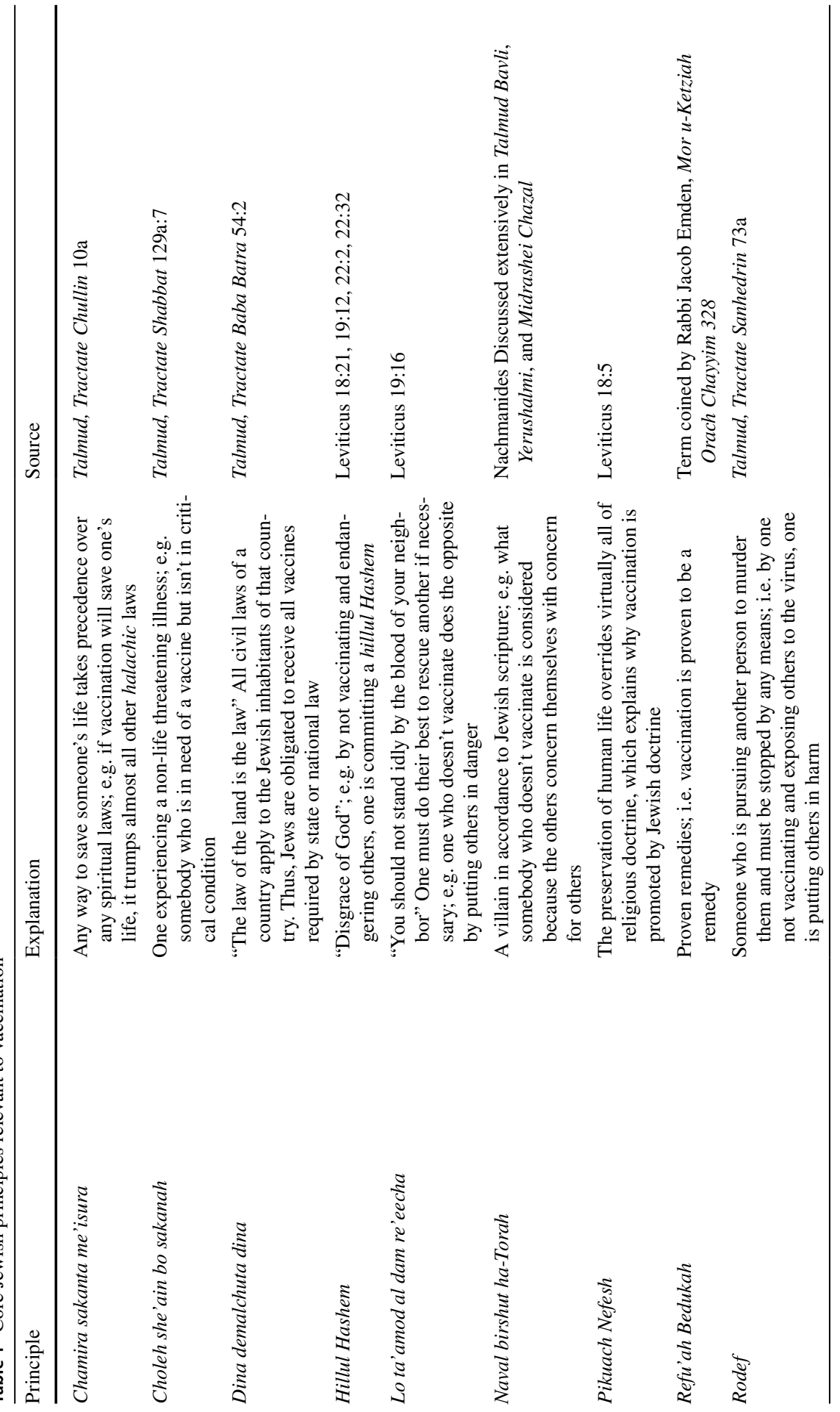




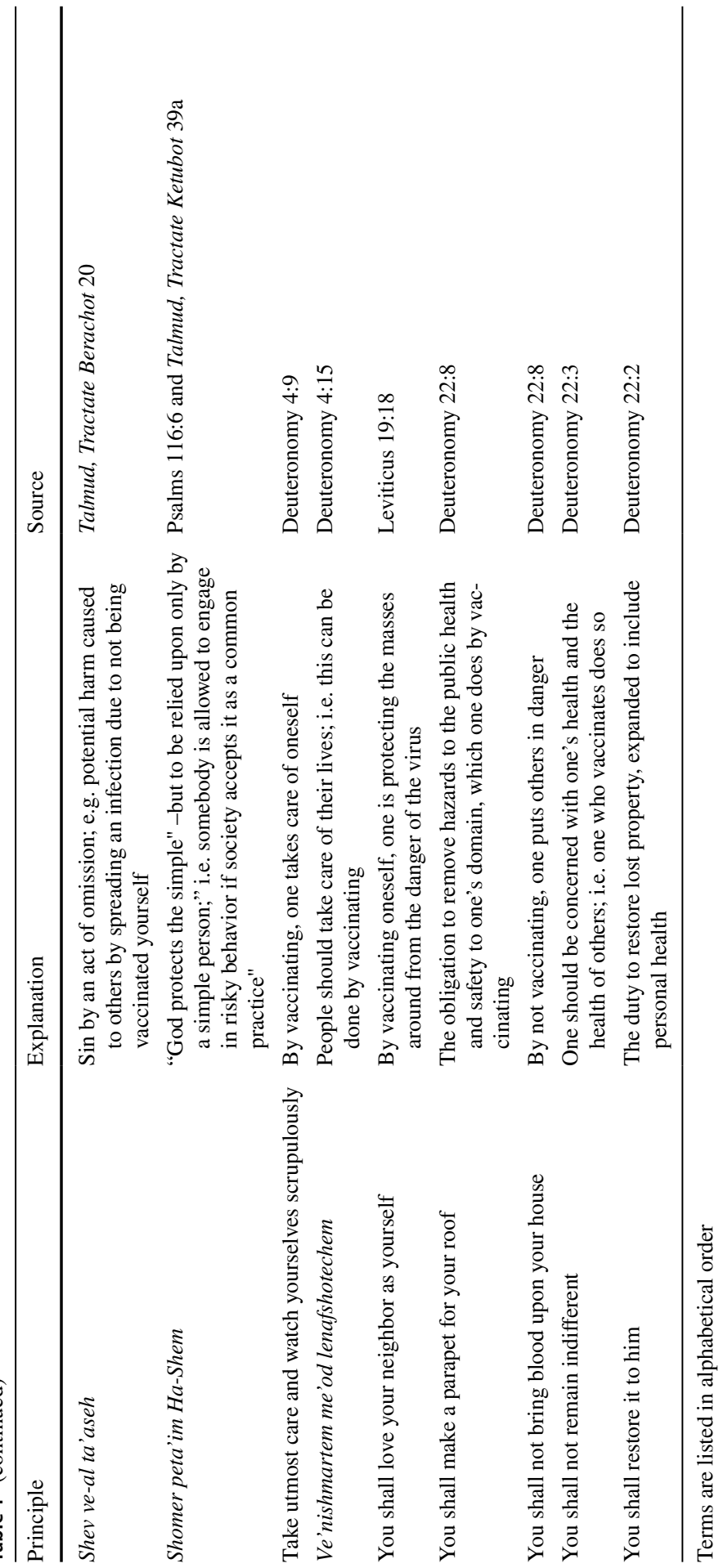




\section{Results}

\section{Common Denominations of Judaism in the USA}

There are three predominant denominations of contemporary American JudaismOrthodox, Conservative, and Reform-with $10 \%$ of American Jews identifying as Orthodox, 18\% as Conservative, and 35\% as Reform (Pew Research Center, 2013). Orthodox Jews adhere to the strict observance of Halacha, the traditional corpus of Jewish law and ethics, and span a spectrum of integration into secular society from the Modern Orthodox to the Haredi (Grazi \& Wolowelsky, 2015). Modern Orthodox Jews are fully integrated in secular society. Children in observant households are often educated in K-12 yeshivahs (Jewish day schools) with parallel secular and religious curricula and then pursue higher secular education. Modern Orthodox rabbis are usually college-educated; the majority are associated with the Rabbi Isaac Elchanan Theological Seminary (RIETS), an affiliate of Yeshiva University (Grazi \& Wolowelsky, 2015). On the other end of the Orthodox spectrum, Haredi communities are not integrated into the secular world and are more insular, internally oriented, and adherent to a traditional religious way of life. Few Haredi Jews complete secular college education, and the secular component of their primary and secondary education programs is often minimal and subsumed by religious learning. Haredi families are, on average, much larger than Modern Orthodox families, with as many as 12 or more children per family (Pew Research Center, 2016). Many Orthodox Jews see themselves somewhere along this spectrum. Among them are adherents to Chabad-Lubavich, a movement within Orthodox Jewish tradition with roots in the mystical and meditative Chassidic movement of eighteenth century Russia.

Conservative Judaism has its roots in the nineteenth century movement founded by Rabbi Zecharias Frankel. Conservative Jews embrace traditional practices and Jewish doctrine, but also integrate modern and egalitarian principles into the way that they observe the Halacha. For example, Orthodox Jews see driving a car on the Sabbath as a transgression, while conservative Jews allow driving to the synagogue on the Sabbath. Similarly, gender-egalitarian prayers are permitted in Conservative synagogues, where in Orthodox synagogues that is strictly forbidden.

Finally, the Reform Jewish movement was founded in nineteenth century Germany and is the largest Jewish denomination in North America (Union for Reform Judaism, 2020). Hebrew Union College-Jewish Institute of Religion is the Reform movement's seminary in North America. Reform Jews believe that the Torah and, by extension, the Halacha are living entities that change and adapt to reflect contemporary realities. Reform Judaism prioritizes individual choice and modernity and seeks to incorporate innovation, as opposed to tradition, into all facets of Jewish life. Another distinctive feature of the Reform movement is the central focus on social justice as a key pillar of the movement (Union for Reform Judaism, 2020). 


\section{Orthodox Judaism Writing on Vaccination}

Core principles of Halacha that inform the vaccination discussion are summarized in Table 1. The primary tenet that drives the halachic imperative to vaccinate is the concept of "pikuach nefesh," which dictates that preservation of human life takes precedence over almost all other religious doctrine and obligation. Rabbinic deliberations on the acceptance of vaccines date back to the eighteenth century when Rabbi Avraham ben Shlomo Nansich urged others to allow inoculation against smallpox after his two children died of the disease. While the Torah authorizes physicians to heal the sick, it was not immediately apparent whether it also allowed them to sicken the healthy with an inoculation to prevent future disease. However, prominent rabbis at the time, including Rabbi Israel Lifschutz (1782-1860), Rabbi Mordechai Banet (1753-1829), Rabbi Eliezer Fleckeles (1754-1826), and Rabbi Ishmael HaKohen (1723-1811), all argued in favor of vaccination because the ultimate benefit was deemed to outweigh the risks. Thus, they ruled that individuals in need of vaccination are classified as "choleh she'ain bo sakanah" (an individual experiencing a non-fatal illness), which allows them to be vaccinated even on the Sabbath.

More recently, writing in Tradition, the Journal of Modern Orthodox Rabbinic Council of America, Rabbi J. Bleich, Professor of Jewish law at Cardozo School of Law and a Rabbinic authority at Yeshivah University's RIETS, concludes that it's illogical for one not to vaccinate against the measles (Bleich, 2020). Rabbi Edward Reichman, MD, Professor of Medicine and Jewish medical ethics at the Albert Einstein College of Medicine, similarly writes that anyone who forgoes vaccination is halachically irresponsible (Reichman, 2008). Thus, in 2018, the Orthodox Union and Rabbinical Council of America issued an unequivocal statement strongly urging vaccination. In their statement, they note the "halachic obligations to care for one's own health as well as to take measures to prevent harm and illness to others" and reiterate the broad consensus of the major poskim (legal scholars who determine positions in Jewish law and ethics; plural for posek) in support of "the vaccination of children to protect them from disease, to eradicate illness from the larger community through so-called herd immunity, and thus to protect others who may be vulnerable" (Orthodox Union, 2018).

The Yerushalmi Terumot, a commentary of rabbinic law, further writes that one must put themselves into minimal danger to save their friend from certain danger. This expands the previous notion that a person must vaccinate to keep themselves out of harm through vaccination by adding that they must also vaccinate to keep others out of harm's way (Galper Grossman \& Grossman, 2020).

Chabad similarly supports vaccination and the Lubavitcher Rebbe, Rabbi Menachem M. Schneerson, frequently spoke out in favor of vaccination (Shurpin, 2018). Indeed, Rabbi Shlomo Zalman Auerback, a widely respected Hasidic rabbi of the nineteenth century, writes that if one's only chance to immunized falls on the Sabbath, it would be permitted (Minchat Shlomo 2:29:4). Haredi religious doctrine also supports vaccination. Rabbi Asher Weiss, a Haredi halachic advisor at Jerusalem's Shaare Zedek Hospital, notes that each Jew has a halachic obligation to vaccinate (Weiss, 2019) and religious leaders in Israel actively advocated in support of vaccination after a 2018 measles outbreak in Jerusalem (Stein-Zamir et al., 2020). 


\section{Conservative Judaism Writing on Vaccination}

The Rabbinical Assembly, the international association of Conservative rabbis, issued a Resolution on Immunization in March 2020 strongly endorsing vaccination (Rabbinical Assembly, 2020), stressing the strong and consistent support for immunization since the 1796 introduction of the smallpox vaccine on the basis of core liturgical and halachic principles. Specifically, the Rabbinical Assembly notes timely vaccination to be a "basic and necessary requirement of appropriate pediatric care," and hence a requirement that aligns with pikuach nefesh as a primary obligation of Jewish law, tradition, and morality. Because infectious childhood diseases and their carriers pose a life-threatening hazard that endangers many people beyond the infected person, and vaccination has the potential to remove this risk at no substantial harm to the vaccinated individual, it should be required without exemption. In his commentary on the mishnah, Rabbi Israel Lipschitz even refers to the creator of the smallpox vaccine in 1796, Dr. Edward Jenner, as "the righteous Jenner"(Rashi, 2020).

Because vaccination is mandated by local governments and agencies, and Jewish law affirms that "Dina demalchuta dina" (the "law of the land is the law"), adherence to secular vaccination mandates may be obligatory. The United States Supreme Court states in its 1944 ruling in Prince vs. Commonwealth of Massachusetts: "the right to practice religion freely does not include liberty to expose the community or the child to communicable disease or the latter to ill health or death" (Prince v. Commonwealth of Massachusetts, 1944). Any Jew that endangers others by not following the law of the land thus causes a hillul Hashem, a disgrace of God.

Importantly, there is no differentiation in the obligation to vaccinate by age. Just as it is commanded on the adult to be vaccinated, so it is also commanded on the parent to vaccinate their child before the child reaches bar/bat mitzvah age. The Conservative Rabbinical Assembly, in their 2020 "Resolution on Immunization" (Rabbinical Assembly, 2020) writes:

- "Parents have a vital religious and moral duty to protect their children from danger and disease with the most effective and appropriate means at their disposal as it says 'Devote your heart to instruction... Do not withhold corrective measures from your child' (Proverbs 23:12-13) and Gersonides' comment: 'Protect your child that he not suffer physical death prematurely.',

- "The self-stigmatizing scandal of immunological recalcitrance and contagion among Jews is inconsistent with our founding, covenantal mission to be a blessing' and an object of blessing to 'all the families of the earth' (Genesis 12:2-3)." In other words, refusing vaccination and endangering those around you would be inconsistent with core Jewish identity and place within humanity.

- 'Rabbi David Tzvi Hoffman (Melamed L'hoi'il 2:104, Frankfurt, 1926) ruled regarding pediatric procedures that 'We do not find anywhere at all in the Torah that parents have a right to endanger the lives of their children by preventing the doctor from treating them.", 
Thus, the Rabbinical Assembly concludes that "unless a specific vaccination is medically contra-indicated for a particular child, and so documented by a reliable physician, refusal to immunize against infectious disease is absolutely inconsistent with Jewish Law, piety, and morality" (Rabbinical Assembly, 2020). Consistent with this view, they unanimously ruled in favor of compulsory immunization requirements by Jewish K-12 schools, further noting that "Failure to immunize children against vaccine-preventable disease is a serious, compound violation of Jewish Law: there is no basis in Halakhah to support a parent's request for a religious exemption from state-mandated immunizations"(Prouser, 2005).

\section{Reform Judaism Writing on Vaccination}

In their Resolution on Mandatory Immunization Laws, the Union for Reform Judaism similarly advocates in favor of mandatory vaccination based on the principles of "pikuach nefesh" and "refu'ah bedukah"(Union for Reform Judaism, 2015). The latter tenet, meant to mandate the acceptance of proven health care therapies, explicitly treats vaccination as a proven medical necessity that should not be refused unless vaccination poses a specific medical harm to the individual. They go further to note that religious exemptions to mandatory vaccination must be suspended "if community immunity is deemed at risk by public health officials"(Union for Reform Judaism, 2015). They evoke the philosopher-physician Maimonides, who had written that "God created food and water; we must use them in staving off hunger and thirst. God created drugs and compounds and gave us the intelligence necessary to discover their medicinal properties; we must use them in warding off illness and disease" (Maimonides's Commentary on Mishnah Pesachim 4:9). Congregations are therefore urged to educate their members on the scientific and religious basis in support of vaccinations and create policies that require vaccination for attendees in programs involving children and youth (Union for Reform Judaism, 2015).

\section{Case Study: MMR Vaccine}

Many religious leaders have written about and strongly advocated in support of universal measles vaccination. Rabbi Aaron Glatt, MD, Chair of the Department of Medicine, Chief of Infectious Diseases, and epidemiologist at Mount Sinai South Nassau, who is also the director of the Halacha and Medicine Commission in the Rabbinical Alliance of America (a national rabbinic organization spanning the spectrum of Orthodox Judaism), explains that vaccination for measles, or any other vaccine for a preventable, fatal illness, is a requirement of all Jews based on the principle of "pikuach nefesh." Building on the early determination that vaccination trumps other religious decrees, i.e. it is permissible on the Sabbath, Rabbi Glatt (Modern Orthodox) notes that vaccinations that include non-kosher materials or are synthetically manufactured are permissible for Jews to use just like porcine valves are permissible for Jews with heart disease despite the general prohibition of pork consumption (Glatt, 2019). Rabbi Weiss (Ultra-Orthodox) goes further to state that a person who does something that the masses are prohibited to do is considered a 
villain in Jewish scripture, or "naval birshut ha-Torah." Anyone who refrains from vaccinating in situations where the population as a whole needs to vaccinate in order to prevent an outbreak (i.e. for the measles) falls into this category. Refraining from vaccinating is therefore a passive act and a sin of omission, known in Jewish law as " "shev ve-al ta'aseh," meaning "to sit and not do."

The mandate to vaccinate does not only apply to the individuals being vaccinated, but to vaccinating their children as well. In response to the 2018 measles outbreaks in the Jewish communities of Israel, New York, and New Jersey, the Av Bet Din (chief rabbinic judge) of the Chicago Rabbinical Council wrote that "it is incumbent upon all members of the community to ensure that they and their children receive the measles vaccination. Even for those not inclined to vaccinate, this is required of them," citing principles of "chamira sakanta me'isura" (if there is a way to save someone's life, it takes precedence over any spiritual laws, reinforcing the supremacy of preserving human life), "ve'nishmartem me'od lenafshotechem" (People should take care of their lives; i.e. it is an obligation to take care of one's life by vaccinating), and "lo ta'amod al dam re'eecha" (You should not stand idly by the blood of your neighbor; i.e. it is a sin to allow someone else to be harmed when you can stop it, i.e. by vaccinating and not spreading the virus) (Reiss \& Fuerst, 2018). Thus, "nobody has the right to endanger others by not vaccinating their children" as that would be a violation of "lo ta'amod al dam re'eecha". For measles, specifically, "exposing others to an unvaccinated individual is equivalent to an act of rodef (someone who is pursuing another person to murder them and must be stopped by any means)" (Reiss \& Fuerst, 2018).

\section{Case Study: HPV Vaccine}

In contrast to the MMR vaccine, HPV vaccination is not consistently required for school entry in the USA (Immunization Action Coalition, 2020; National Conference of State Legislatures, 2021). Because HPV is transmitted primarily through sexual contact, religious communities and leaders have often been hesitant to mandate or definitively recommend it, particularly for younger children. Many in the Orthodox community are resistant to HPV vaccination out of concern that it condones or promotes sexual activity. Others may view their community as being at lower risk for a sexually transmitted disease and thus not in need of vaccination (Galper Grossman, 2019; Gordon et al., 2011). Thus, HPV vaccination rates in Israel, and particularly in Jerusalem where a higher proportion of the population is Orthodox, are much lower than rates of vaccination against other infections (Galper Grossman, 2019).

Some religious authorities hold that vaccination against HPV can be viewed differently from other vaccines. Rabbi Bleich contrasts the HPV vaccine to the MMR, arguing the measles is both associated with greater morbidity than HPV and has greater risk for transmission. Therefore, he concludes that while one would be illogical to not vaccinate against measles, there is not a similar absolute halachic obligation to vaccinate against HPV (Bleich, 2020). Nevertheless, because the vaccine is otherwise safe, it can be generally recommended even if not halachically required. 
This falls under the purview of "shomer peta'im Ha-Shem," meaning that someone who does not vaccinate can be considered a "simple person" because vaccination is generally accepted as common practice in society and carries a minimal risk. Rabbi Bleich does recommend that the HPV vaccine be given to all members of the Jewish community a few years prior to sexual initiation rather than at the otherwise recommended schedule of 11-12 years, which he argues is later for Orthodox youth than the general population. He advises starting the vaccination series at age 16 for girls and 18 for boys, though suggests that they consult with their physician for the age that is right for them (Bleich, 2020). However, not all Orthodox poskim share this view. For example, Rabbi Moshe Feinstein dispels the notion that the HPV vaccine can promote promiscuity and qualifies as an 'aiding and abetting' sin because there is no guarantee that vaccinating individuals against HPV will lead them to sin. He notes that this situation is analogous to whether one should be allowed to learn how to drive during the week despite no guarantee that they will not drive on Shabbat, which is a sin (Galper Grossman, 2019).

Importantly, Halacha does not stipulate a dose effect or threshold level of risk on the mandate to avoid harm and prevent illness. According to Shulhan Arukh Hoshen Mishpat 427:5, an individual is obligated to build a parapet even for a room that is at low height despite the minimal risk of a fall and injury at such height and even when the process of building this parapet may cause injury to the builder. In other words, one is required to take steps to prevent harm (i.e. be vaccinated) even when the risk of harm is very low (i.e. infection is unlikely) and there is small risk of harm to self (i.e. side effects of the vaccination) in the process (Galper Grossman, 2019). Thus, principles supporting vaccination more broadly apply to HPV as well.

Further supporting the recommendation to vaccinate against HPV, Rabbi Eliyashiv - a Haredi rabbi regarded as the posek ha-dor, or the preeminent contemporary leading authority on the Halacha-writes that because the HPV vaccine was endorsed by the World Health Organization and more than 100 countries, the Jews should follow their guidance. Failing to vaccinate one's children can amount to negligence, be irresponsible, and is not supported by the Halacha (Galper Grossman, 2019). The Reform movement takes an even stronger stance in support of HPV vaccination. Rabbi Michael Melen, the past director of the Reform Jewish Youth Movement, argues that the HPV vaccine is aligned with Jewish ethics and strongly advocates for its use (Mellen, 2012). In Israel, the only place with available data for Jewish communities specifically, coverage rate for the HPV vaccine in the Reform community is $70-80 \%$ compared to $0-35 \%$ for those in the ultra-Orthodox and Orthodox communities (Velan \& Yadgar, 2017).

\section{Case Study: COVID-19 Vaccine}

Literature about Jewish attitudes toward COVID-19 vaccination is beginning to emerge and points toward both acceptability and halachic support for vaccination (Galper Grossman \& Grossman, 2020). Principles relevant to the vaccine against COVID-19 are comparable to those against measles, as both are highly communicable and potentially life threatening infections. Even though the COVID-19 vaccine is 
new, the benefits of vaccination for the individual, their community, and society far outweigh any potential risks. This is reflected by the "COVID-19 Vaccine Guidance" issued by the Orthodox Union and the Rabbinical Council of America in December 2020 (Orthodox Union, 2020). Special consideration is given to the facts that COVID-19 vaccines were developed with unprecedented speed and that two leading vaccine candidates at the time (both currently approved by the USA Food and Drug Administration under Emergency Use Authorizations) use new mRNA technologies. Nevertheless, the poskim conclude that "the Torah obligation to preserve our lives and the lives of others requires us to vaccinate for COVID-19 as soon as a vaccine becomes available." Thus, Rabbis Chaim Kanievsky, Gershon Edelstein, and Shalom Cohen, the pre-eminent Haredi rabbis in Israel, assert that "anyone who has the option of getting the vaccine should do it" (Times of Israel, 2020).

The Committee on Jewish Law and Standards of the Rabbinical Assembly (Conservative) similarly strongly endorsed vaccination against COVID-19 as well as other efforts to curb the spread of this disease. In a unanimous ruling, the Committee states that "taking preventative measures during this time of pandemic, like wearing masks, washing hands, and maintaining physical distancing, are not just recommended but are obligated by the Halacha. If there is even a chance that our behavior can protect our lives, and the lives of others, then that would take precedence over any other consideration. When it comes to vaccines, we can say much of the same thing." Drawing inferences from multiple sources and discussions surrounding Edward Jenner's smallpox vaccine, the Committee further noted that vaccination against COVID-19 must proceed despite potential risks associated with these new vaccines as the presumed risks of the vaccines must be weighed against the real risks of contracting COVID-19. Indeed, the level of testing that occurred met halachic criteria for refuah b'dukah (established treatment), allowing for vaccination against COVID-19 to be deemed mandatory (Peltz, 2021).

The Reform movement has yet to issue specific guidance regarding the COVID19 vaccine, though the Central Conference of American Rabbis issued a statement early on in the pandemic reinforcing the supremacy of pikuach nefesh (the saving of lives) as the highest mitzvah in Jewish tradition. They further noted that the "permanent eradication of the coronavirus ultimately depends upon the development of an affective vaccine" (Segal and Person 2020). Whether the Reform movement will issue a Responsa or Resolution in support of vaccination against COVID-19 remains to be seen, though the Central Conference of American Rabbis has previously been very supportive of vaccination in general and there is no reason to believe that they would view COVID-19 differently.

\section{Discussion}

Jewish law is strongly and invariably supportive of vaccination, including mandatory vaccination with suspension of non-medical exemptions if the health of the surrounding community is at stake. Halachic views do not provide a deterrent for Jews to inoculate; rather, it would be "halachically irresponsible" to not vaccinate. No posek has ever stated that vaccination is prohibited by the doctrine of any 
denomination of Judaism. Awareness of and appreciation for these religious principles are critical for the development and implementation of successful culturally appropriate and culturally sensitive communication strategies aimed at enhancing vaccination efforts.

Better understanding of Judaism's tenets surrounding vaccination may help clinicians and public health professionals counsel individuals and families on the need for vaccination while simultaneously respecting and adhering to their belief systems. Education efforts are more likely to be successful if contextualized in the tradition the patient follows, particularly as Jewish law and tradition both explicitly endorse vaccination against all clinically relevant conditions. We believe that public health programs aimed at members of religious groups are most effective when organized in partnership with respected community leaders and grounded in the core principles of their faith. Rabbinical support of vaccination can be effective, as evidenced by the substantial increase in vaccination rates against measles (Stein-Zamir and Abramson et al. 2020) and COVID-19 (Times of Israel, 2020) in the Haredi communities of Israel.

\section{Limitations}

While we examine and contextualize the Jewish perspectives on vaccination and focus on all three major denominations of American Judaism rather than on the Orthodox perspective alone, our findings may not generalize to Jews who do not affiliate themselves with any of these denominations or to members of other faiths. Further work is needed to examine the spectrum of attitudes of other faiths and religious groups, which would aid clinicians when counseling members of these groups. Moreover, the degree to which official religious doctrine shapes the attitudes and behaviors of individual people is likely variable, and has not been examined.

\section{Conclusion}

All Jewish doctrine supports immunization and discourages non-medical exemptions. Clinicians, public health professionals, and community activities may want to leverage this information when engaging with Jews and Jewish communities across the religious spectrum to encourage vaccination efforts. This is especially important at the present time, as governments, public health organizations, and health systems work toward eradication of the COVID-19 pandemic through large-scale vaccination.

Acknowledgements We are grateful to Joel B. Wolowelsky, PhD (Yeshivah of Flatbush Joel Braverman High School, Brooklyn, NY) and Rabbi Shloime Greene (Executive Vice President, Chabad of Southern Minnesota, Rochester, MN) for their guidance and feedback on this manuscript.

Authors' Contributions Material preparation, data collection, and data synthesis were performed by Ms. NLM and GMB. The first draft of the manuscript was written by NLM and GMB. RGM conceived and supervised the study. All authors commented on previous versions of the manuscript and read and approved the final manuscript. 
Funding The authors did not receive support from any organization for the submitted work. Dr. McCoy is supported by the National Institute of Health National Institute of Diabetes and Digestive and Kidney Diseases Grant No K23DK114497.

\section{Declarations}

Conflict of interest The authors declare that they have no conflict of interest.

\section{References}

Andrews, M. (2019, March 11). "Why Measles Hits So Hard Within N.Y. Orthodox Jewish Community." Retrieved April 21, 2021 from https://khn.org/news/why-measles-hits-so-hard-within-n-y-orthodoxjewish-community/

Bednarczyk, R. A., King, A. R., Lahijani, A., \& Omer, S. B. (2019). Current landscape of nonmedical vaccination exemptions in the United States: Impact of policy changes. Expert Review of Vaccines, 18(2), 175-190. https://doi.org/10.1080/14760584.2019.1562344

Bleich, D. J. (2020). Personal communication via e-mail with Joel B. Wolowelsky.

CDC. (2020). "Measles Cases and Outbreaks." Retrieved September 10, 2020 from https://www.cdc.gov/ measles/cases-outbreaks.html.

CDC. (2021). "COVID Data Tracker." Retrieved October 15, 2021 from https://covid.cdc.gov/covid-datatracker/\#vaccinations

Galper Grossman, S. (2019). "Resolving the Debate Over Human Papilloma Virus (HPV) Vaccination for Cancer Prevention in the Religious World.” Tradition. 51(2):50-75. Retrieved April 21, 2021 from https://traditiononline.org/resolving-the-debate-over-human-pappiloma-virus-hpv-vaccination-forcancer-prevention-in-the-religious-world/

Galper Grossman, S. and Grossman, S. (2020). "Halakha Approaches the COVID-19 Vaccine." Tradition Online. Posted October 20, 2020. Retrieved December 25, 2020 from https://traditiononline.org/ halakha-approaches-the-covid-19-vaccine/?utm_source=rss\&utm_medium=rss\&utm_campaign= halakha-approaches-the-covid-19-vaccine.

Glasser, J. W., Feng, Z., Omer, S. B., Smith, P. J., \& Rodewald, L. E. (2016). The effect of heterogeneity in uptake of the measles, mumps, and rubella vaccine on the potential for outbreaks of measles: a modelling study. Lancet Infectious Diseases, 16(5), 599-605. https://doi.org/10.1016/S14733099(16)00004-9

Glatt, A. (2019) "Vaccination is Pikuach Nefesh." Retrieved December 25, 2020 from https://rabbinical alliance.org/2019/04/10/vaccination-is-pikuach-nefesh

Gordon, D., Waller, J., \& Marlow, L. A. V. (2011). Attitudes to HPV vaccination among mothers in the british jewish community: reasons for accepting or declining the vaccine. Vaccine, 29(43), 73507356. https://doi.org/10.1016/j.vaccine.2011.07.083

Grazi, R. V., \& Wolowelsky, J. B. (2015). Cultural concerns when counseling orthodox jewish couples for genetic screening and PGD. Journal of Genetic Counseling, 24(6), 878-881. https://doi.org/10. 1007/s10897-015-9860-6

Immunization Action Coalition. (2020). "State Mandates on Immunization and Vaccine-Preventable Diseases." Updated on February 24, 2020. Retrieved December 24, 2020 from https://www.immunize. org/laws/laws-exemptions.asp.

Jiang, D. H., Roy, D. J., Gu, B. J., Hassett, L. C., McCoy, \& R. G. (2021). "Postacute Sequelae of Severe Acute Respiratory Syndrome Coronavirus 2 Infection: A State-of-the-Art Review.” JACC: Basic to Translational Science Online ahead of print Sept 15. https://doi.org/10.1016/j.jacbts.2021.07.002

Jiang, D. H., \& McCoy, R. G. (2020). Planning for the post-COVID syndrome: How payers can mitigate long-term complications of the pandemic. Journal of General Internal Medicine, 35(10), 30363039. https://doi.org/10.1007/s11606-020-06042-3

Kruzel, J. (2020). "Supreme Court Sees New Requests for Religious COVID-19 Carve-outs." The Hill Posted December 3, 2020. Accessed October 5, 2021 from https://thehill.com/regulation/court-battl es/528505-supreme-court-sees-new-requests-for-religious-covid-19-carve-outs 
Levenson, E., Sgueglia, K., and Schuman, M. (2020). "New York Sees Startling Uptick in COVID-19 Cases in Orthodox Jewish Neighborhoods". CNN. Posted on September 30, 2020. Accessed October 5, 2021 from https://www.cnn.com/2020/09/30/us/new-york-city-covid-orthodox-jewish/index. html

Mellen, M. (2012). "Get the HPV Vaccine," Says Jewish Ethics." Posted October 25, 2020. Retrieved December 25, 2020, from https://reformjudaism.org/blog/get-hpv-vaccine-says-jewish-ethics.

National Conference of State Legislatures. (2021). "States with Religious and Philosophical Exemptions From School Immunization Requirements.” Posted January 29, 2021. Retrieved April 21, 2021 from https://www.ncsl.org/research/health/school-immunization-exemption-state-laws.aspx

Peltz, M. (2021). "HM 427:8.2021a: Vaccination and Ethnical Questions Posed by COVID-19 Vaccines." Committee on Jewish Law and Standards of the Rabbinical Assembly. Retrieved July 15, 2021 from https://www.rabbinicalassembly.org/sites/default/files/2020-12/Vaccination\%20and\%20Ethical\% 20Questions\%20Posed $\% 20$ by $\%$ 20COVID-19\%20Vaccines $\% 20-\% 20$ Final $\% 20$ Jan $\% 201 \% 20 \% 281 \%$ 29.pdf

Pew Research Center. (2013). "A Portrait of Jewish Americans." Posted October 1, 2013. Retrieved December 25, 2020 from https://www.pewforum.org/2013/10/01/jewish-american-beliefs-attitudesculture-survey

Pew Research Center. (2015). U.S. Public Becoming Less Religious. Religious Landscape Study. Retrieved April 21, 2021 from https://www.pewforum.org/2015/11/03/u-s-public-becoming-lessreligious/

Pew Research Center. (2016). "A Portrait of American Orthodox Jews." Posted August 26, 2016. Retrieved December 25, 2020 from https://www.pewforum.org/2015/08/26/a-portrait-of-americanorthodox-jews.

Prince, V. (2021). Commonwealth of Massachusetts. United States Supreme Court 1944. Retrieved July 15, 2021 from https://www.law.cornell.edu/supremecourt/text/321/158

Prouser, J. H. (2005). HM 427:8.2005. Compulsory Immunization in Jewish Day Schools, Rabbinical Assembly. Retrieved July 15, 2021 from https://www.rabbinicalassembly.org/sites/default/files/public/halakhah/teshuvot/20052010/prouser_immunization.pdf

Rabbinical Assembly. (2020). "Resolution on Immunization." Posted March 24, 2020. Retrieved September 11, 2020 from https://www.rabbinicalassembly.org/story/resolution-immunization-1.

Rashi, T. (2020). Jewish ethics regarding vaccination. Public Health Ethics, 13(2), 215-223. https://doi. org/10.1093/phe/phaa022

Reichman, E. (2008). "Halachic Aspects of Vaccination.” . Jewish Action. 69:2(Winter, 2008), 10-14. Retrieved on October 5, 2021 from https://jewishaction.com/religion/jewish-law/halachic_aspects_ of_vaccination/?webSyncID=377d8db7-6a32-a23a-8997-0233600c237d \&sessionGUID=03c37 5b4-19d2-9c67-5b29-403d17921bc7

Reiss, Y. and Fuerst, S. (2018). "Measles Vaccination Letter to the Chicago Jewish Community." Posted November 13, 2018. Retrieved January 2, 2021 from https://images.shulcloud.com/434/uploads/ measles-vaccination-letter---Reiss-and-Feurst-111318.pdf

Salmon, D. A., Haber, M., Gangarosa, E. J., Phillips, L., Smith, N., \& Chen, R. T. (1999). Health consequences of religious and philosophical exemptions from immunization laws: Individual and societal risk of measles. JAMA, 282(1), 47-53.

Segal, R. and Person, H. (2020). "Central Conference of American Rabbis Statement on the Primary of Saving Lives During the COVID-10 Crisis." Retrieved on July 15, 2021 from https://www.ccarnet. org/central-conference-of-american-rabbis-statement-on-the-primacy-of-saving-lives-covid-19/

Shurpin, Y. (2018). "What Does Jewish Law Say About Vaccination?" Retrieved January 2, 2021 from https://www.chabadrochestermn.com/library/article_cdo/aid/2870103/jewish/What-Does-JewishLaw-Say-About-Vaccination.htm.

Stein-Zamir, C., Abramson, N., \& Shoob H. (2020). "Notes from the Field: Large Measles Outbreak in Orthodox Jewish Communities - Jerusalem District, Israel, 2018-2019." MMWR Morbidity Mortality Weekly Report 69(18): 562-563. http://dx.doi.org/https://doi.org/10.15585/mmwr.mm6918a3

Times of Israel. (2020). "Top Ultra-Orthodox Rabbis Recommend Community Vaccinate Against COVID-19.” Posted December 15, 2020. Retrieved April 21, 2021 from https://www.timesofisrael. com/top-ultra-orthodox-rabbis-recommend-community-vaccinate-against-covid-19/

Union for Reform Judaism. (2015). "Resolution on Mandatory Immunization Laws, Commission on Social Action of Reform Judaism." Retrieved on October 5, 2021 from https://urj.org/what-we-belie ve/resolutions/resolution-mandatory-immunization-laws 
Orthodox Union. (2018). "Statement on Vaccinations from the OU and Rabbinical Council of America." Posted November 14, 2018. Retrieved January 2, 2021, from https://www.ou.org/news/statementvaccinations-ou-rabbinical-council-america/.

Orthodox Union. (2020). "COVID-19 Vaccine Guidance." Presented by the Orthodox Union and the Rabbinical Council of America on December 15, 2020. Retrieved September 2, 2021 from https:// www.ou.org/assets/Guidance-re-Vaccines.pdf

Union for Reform Judaism. (2020). "The Reform Movement in North America." Retrieved December 25, 2020 from https://urj.org/who-we-are/reform-movement-north-america.

Velan, B., \& Yadgar, Y. (2017). On the implications of desexualizing vaccines against sexually transmitted diseases: Health policy challenges in a multicultural society. Israeli Journal Health Policy Research, 6(1), 30. https://doi.org/10.1186/s13584-017-0153-4

Wang, E., Clymer, J., Davis-Hayes, C., \& Buttenheim, A. (2014). Nonmedical exemptions from school immunization requirements: A systematic review. American Journal of Public Health, 104(11), e6284. https://doi.org/10.2105/AJPH.2014.302190

Weiss, A. (2019). "Is It Permissible to Refrain from Vaccinating Children?" Retrieved December 25, 2020 from https://www.torahmusings.com/2019/04/is-it-permissible-to-refrain-from-vaccinatingchildren/.

Publisher's Note Springer Nature remains neutral with regard to jurisdictional claims in published maps and institutional affiliations. 